Fossi, C. \& Renzoni, A. (1989). Metabolic adaptations of certain seagulls to our changing world. Environmental Conservation, 16(4), pp. 356-7.

JARVIS, P.J. (1990). Urban cats as pests and pets. Environmental Conservation, 17(2), pp. 169-71.

GUTHOVÁ, ZUZANA (1993). Variations in reproduction parameters of Black-headed Gulls (Larus ridibundus) living in different conditions in the Czech and Slovak Republics. Environmental Conservation, 20(4), pp. 347-51 (5 figs and 3 tables).

LEVETT, R. (1993). Earth Summit--Rio '92. Supplement $\mathrm{Nr} 2$. (Agenda 21: A Guide For Local Authorities in The UK.) Local Government Management Board, Luton, England, UK: [not available for checking].

Proulx, G. (1988). Control of urban wildlife predation by cats through public education. Environmental Conservation, 15(4), pp. 358-9 (4 figs).

REss, P.E. (1989). Cities in distress: WHO sounds the alarm. Environmental Conservation, 16(4), pp. 366-7 (fig.).
SHAW, R.P. (1989). Rapid population growth and environmental degradation: ultimate versus proximate factors. Environmental Conservation, 16(3), pp. 199-208 (3 figs and table).

ZHoU, M.M., YI, L.J., BERTINE, K.K., KoIDE, M. \& GoldBERG, E.D. (1989). Atmospheric pollution in Beijing, China, as recorded in sediments of the Summer Palace Lake. Environmental Conservation, 16(3), pp. 233-6 (fig. and 5 tables).

GERALD F.M. DAWE, Editor

KEITH GRICE, Managing Editor

Urban Nature Magazine

Urban Environment

40 Milford Road

Birmingham B17 9RL

England, UK.

\title{
IIASA Goes Global
}

$\mathrm{T}^{\mathrm{s}}$ he International Institute for Applied Systems Analysis (IIASA, of Laxenburg, Austria) is an interdisciplinary, nongovernmental research institution that is sponsored by a consortium of National Member Organizations in 17 nations. The Institute conducts international and interdisciplinary scientific studies to provide timely and relevant information and options, addressing critical issues of global environmental, economic, and social, changes, for the benefit of the public, the scientific community, and national and international institutions. Its research programme focuses on three central themes: Global Environmental Change; Global Economic and Technological Transitions; and Systems Methods for the Analysis of Global Issues.

The establishment of a new North-South Fund has been announced by Dr Peter E. de Jánosi, Director of IIASA. The Fund is intended to increase the involvement of scientists from the developing world in the research work carried out at IIASA. Although founded as an EastWest Institute, IIASA has, since its inception in 1972, also worked on international and global problems; indeed, with the end of the Cold War, the Institute's agenda has focused on problems of global change. This fact was recognized in the awarding of a two-years' grant by the Rockefeller Foundation of New York, beginning in May 1994. This grant provides the seed money for IIASA's North-South Fund, which is expected to be supplemented from other sources.
The Institute's current agenda calls for the study of human, environmental, and economic, dimensions of global change. This includes the less-industrialized countries of the Southern hemisphere, many of which are striving to meet development goals in the face of mounting urban pressures, population growth, rapid social change, and widespread environmental constraints.

'There is a clear need for the perspective and inputs of researchers from the South in the study of solutions to the global problems that IIASA now addresses', says Dr de Jánosi. "Most of the projects at the Institute already have excellent connections world-wide, so we expect no difficulty in locating and recruiting the talent that is available', he adds. The establishment of the North-South Fund, which effectively begins with this grant from the Rockefeller Foundation, will ensure financial support for selected scholars from developing countries to work at IIASA. The inclusion of a North-South view will expand IIASA's horizons without detracting from its traditional East-West connections and perspectives.

\section{ELISABETH KRIPPL, Head Public Information IIASA}

A-2361 Laxenburg

Austria.

\section{The Almería Statement on Desertification and Migration *}

$\mathrm{W}$ e must protect the land that feeds us. Following upon the United Nations Conference on Environment and Development, held in Rio de Janeiro in June 1992, and based on recommendations contained in Agenda 21, particularly its Chapter 12 on 'Managing fragile ecosystems: combating desertification and drought', the General Assembly of the United Nations decided to establish an Intergovernmental Negotiating Committee for the Elaboration of an International Convention to

* Emanating from the International Symposium on Desertification and Migration, held in Almería, Spain, during 9-11 February 1994, as reported on pages $85-6$ of our preceding issue by Dr Arthur H. Westing who communicated this statement. - Ed.
Combat Desertification in those countries experiencing serious drought and/or desertification, particularly in Africa [Res. 47/188, 22 Dec. '92].

Desertification is a global phenomenon, affecting all continents, engendering cross-boundary and transcontinental migrations, and forcing people in vulnerable areas [that have been] marginalized by poverty and ecological degradation, to look for better living opportunities in cities, other regions, or other countries, where further strains on the natural and social environments are apt to occur.

We must face the issues confronting the people who inhabit affected arid lands. The General Assembly of the United Nations called for an International Conference on 